\title{
MEMBANGUN KOMPETENSI PEDAGOGIK DAN KETERAMPILAN DASAR MENGAJAR BAGI MAHASISWA MELALUI LESSON STUDY
}

\author{
SYOFNIDAH IFRIANTI \\ Email: syofnidah ifrianti@ radenintan.ac.id
}

JURUSAN PGMI FAKULTAS TARBIYAH DAN KEGURUAN

\begin{abstract}
Abstrak
Sebagai calon guru, para mahasiswa Prodi PGMI dibekali empat kompetensi yang harus dikuasai oleh guru, yaitu: kompetensi pedagogik, kompetensi kepribadian, kompetensi sosial, dan kompetensi profesional yang diperoleh melalui pendidikan profesi. Dalam penelitian ini dikembangkan kompetensi pedagogik dan keterampilan dasar mengajar mahasiswa melalui Lesson Study.

Jenis penelitian ini adalah penelitian lapangan dengan sifat penelitian deskriptif kualitatif. Adapun subyek penelitian adalah mahasiswa semester VI Prodi PGMI Fakultas Tarbiyah dan Keguruan UIN Raden Intan Lampung. Pengumpulan data penelitian dilakukan melalui triangulasi sumber data dan triangulasi metode. Triangulasi sumber data dilakukan untuk mengecek kebenaran data yang sama dari tiga sumber yang berbeda. Sedangkan triangulasi metode dilakukan untuk mengecek kebenaran data melalui tiga teknik yang berbeda, yaitu observasi, wawancara, dan dokumen.

Berdasarkan analisa data, diperoleh kesimpulan sebagai berikut: (1) Pelaksanaan lesson study menumbuhkan kompetensi pedagogik dan keterampilan dasar mengajar mahasiswa melalui komitmen yang kuat dari seluruh anggota tim, proses latihan mengajar yang terencana secara seksama, pelaksanaan yang dilakukan dengan tahapan yang sistematis dan berkelanjutan, serta saling memberi dan menerima saran dari orang lain.; (2) Kendala yang dihadapi: a) Keberadaan observer dapat mengganggu konsentrasi pengajar, b) observer hanya mencatat kesalahan/kekurangan selama proses pembelajaran, c) Kebanyakan fokus pengamatan pada guru, bukan pada proses pembelajaran, d) Pada tahapan diskusi, mahasiswa saling mengritik dan mengemukakan kelemahan rekannya; (3) Manfaatnya: a) mengamati dan belajar dari pengalaman orang lain, b) kualitas pembelajaran yang lebih baik, c) Melatih mahasiswa untuk lebih teliti dalam menentukan tujuan pembelajaran, mengenal cara berpikir peserta didik, dan memilih metode pembelajaran yang tepat, d) Dapat mengembangkan keahlian mengajar baik dalam perencanaan maupun selama proses pembelajaran.
\end{abstract}

Kata Kunci: kompetensi pedagogik, keterampilan dasar mengajar

Membangun kompetensi pedagogik dan keterampilan dasar mengajar bagi mahasiswa melalui lesson study 


\section{A. PENDAHULUAN}

Berdasarkan isi Undang-Undang No 20 Tahun 2003 tentang Sistem Pendidikan Nasional, dunia pendidikan ditantang untuk membentuk generasi yang berkualitas. Salah satu unsur yang mengembang tugas mulia tersebut adalah guru. Untuk menghasilkan generasi yang berkualitas, tentu harus didahului dengan terciptanya guru-guru yang berkualitas pula. Dibutuhkan keterampilanketerampilan khusus agar dapat menjadi guru yang berkulitas. Seorang guru harus menguasai beberapa kompetensi, sebagaimana tercantum dalam Undang-Undang Nomor 14 Tahun 2005 tentang Guru dan Dosen, pada pasal 10 ayat (1) menyatakan bahwa "Kompetensi guru sebagaimana dimaksud dalam Pasal 8 meliputi kompetensi pedagogik, kompetensi kepribadian, kompetensi sosial, dan kompetensi profesional yang diperoleh melalui pendidikan profesi”

Fokus penelitian ini adalah pengembangan kompetensi pedagogik. Kompetensi pedagogik guru harus terus dikembangkan dari waktu ke waktu sehingga guru mampu merencanakan, melaksanakan, mengevaluasi dan menindaklanjuti hasil evaluasi pembelajaran. Terkait dengan kompetensi pedagogik, seorang guru harus menguasai keterampilan dasar mengajar.

Secara garis besar, keterampilan dasar mengajar terdiri dari: (a) Keterampilan membuka; (b) Keterampilan menutup; (c) Keterampilan menjelaskan; (d) Keterampilan mengadakan variasi stimulus; (e) Keterampilan bertanya dasar; (f) Keterampilan bertanya lanjut; (g) Keterampilan memberi balikan dan penguatan; (h) Keterampilan membimbing diskusi; (i) Keterampilan mengajar kelompok kecil \& perorangan; (j) Keterampilan membuat ilustrasi dan contoh; (k) Keterampilan mengelola kelas.

Sebagai calon guru, para mahasiswa Prodi PGMI dibekali keempat kompetensi yang harus dikuasai oleh guru. Seperti telah diuraikan terdahulu bahwa salah satu kompetensi yang dimaksud adalah kompetensi pedagogik, maka dalam penelitian ini akan dikembangkan kompetensi pedagogik dan keterampilan dasar mengajar mahasiswa melalui Lesson Study. 
Lesson Study merupakan proses belajar dalam kegiatan pembelajaran. Lesson Study dapat dikatakan sebagai upaya pembinaan untuk meningkatkan proses pembelajaran yang dilakukan oleh sekelompok guru atau calon guru secara kolaboratif dan berkesinambungan, baik dalam merencanakan, melaksanakan, mengobservasi dan melaporkan hasil pembelajaran. Melalui Lesson Study mereka dapat berdikusi, mengobservasi, melakukan refleksi, dan meningkatkan keterampilan mengajar dari waktu ke waktu. Lesson Study juga mendorong pemikiran mereka mengenai bagaimana cara mereka mengajar, bukan hanya pada apa yang mereka ajarkan.

\section{B. KAJIAN TEORI}

\section{Kompetensi Pedagogik}

Kompetensi Pedagogik menurut Standar Nasional Pendidikan (NSP) pasal 26 ayat (3) adalah kemampuan pemahaman terhadap peserta didik, perancangan dan pelaksanaan pembelajaran, evaluasi hasil belajar, dan pengembangan peserta didik untuk mengaktualisasikan berbagai potensi yang dimilikinya.

Sub kompetensi dalam kompetensi Pedagogik adalah :

a. Memahami peserta didik secara mendalam yang meliputi memahami peserta didik dengan memamfaatkan prinsip-prinsip perkembangan kognitif, prinsipprinsip kepribadian, dan mengidentifikasi bekal ajar awal peserta didik.

b. Merancang pembelajaran, termasuk memahami landasan pendidikan untuk kepentingan pembelajaran yang meliputi memahami landasan pendidikan, menerapkan teori belajar dan pembelajaran, menentukan strategi pembelajaran berdasarkan karakteristik peserta didik, kompetensi yang ingin dicapai, dan materi ajar, serta menyusun rancangan pembelajaran berdasarkan strategi yang dipilih.

c. Melaksanakan pembelajaran yang meliputi menata latar (setting) pembelajaran dan melaksanakan pembelajaran yang kondusif.

d. Merancang dan melaksanakan evaluasi pembelajaran yang meliputi merancang dan melaksanakan evaluasi (assessment) proses dan hasil belajar Membangun kompetensi pedagogik dan keterampilan dasar mengajar bagi mahasiswa melalui lesson study 
secara berkesinambungan dengan berbagai metode, menganalisis hasil evaluasi proses dan hasil belajar untuk menentukan tingkat ketuntasan belajar (mastery level), dan memanfaatkan hasil penilaian pembelajaran untuk perbaikan kualitas program pembelajaran secara umum.

e. Mengembangkan peserta didik untuk mengaktualisasikan berbagai potensinya meliputi memfasilitasi peserta didik untuk pengembangan berbagai potensi akademik, dan memfasilitasi peserta didik untuk mengembangkan berbagai potensi non akademik.

\section{Implementasi Kompetensi Pedagogik}

Secara sederhana terdapat empat (4) komponen yang harus dikuasai guru dalam mengimplementasi kompetensi pedagogik, yaitu: pemahaman teori pembelajaran dan kurikulum; persiapan pembelajaran; pelaksanaan pembelajaran; pelaksanaan evaluasi dan tindak lanjut.

Pemahaman teori pembelajaran dan kurikulum mendorong guru untuk menguasai teori belajar dan prinsip-prinsip pembelajaran yang mendidik. Selain itu juga mendorong guru untuk memahami dan mengenal karakteristik peserta didik, menguasai berbagai pendekatan, strategi, metode, serta teknik pembelajaran yang kreatif dan inovatif.

Perencanaan pembelajaran meliputi banyak hal, seperti: menyusun program tahunan, program semester, silabus, dan RPP. Guru yang profesional dapat dilihat dari kemampuannya yang baik dalam merencanakan kegiatan pembelajaran secara detil dan lengkap. Sehingga ketika memulai suatu proses pembelajaran, guru sudah sepenuhnya siap sesuai dengan tujuan yang ingin dicapainya.

Pelaksanaan pembelajaran yang mendidik dan dialogis biasanya disebut juga dengan istilah standar proses. Seorang guru disebut profesional jika ia dapat melaksanakan pembelajaran sesuai dengan standar proses. Kemampuan guru dalam menerapkan model pembelajaran kreatif-inovatif merupakan salah satu indikator penting dalam kompetensi pedagogik.

Membangun kompetensi pedagogik dan keterampilan dasar mengajar bagi mahasiswa melalui lesson study 
Evaluasi hasil belajar dilakukan untuk mengetahui berhasil atau tidaknya suatu proses pembelajaran. Sebaiknya guru menguasai prosedur kegiatan evaluasi dan hal-hal terkait seperti membuat kisi-kisi soal dan sistem penilaian. Yang tidak kalah pentingnya adalah kemampuan guru dalam memanfaatkan hasil penilaian untuk kepentingan tindak lanjut pembelajaran.

\section{Keterampilan Dasar Mengajar}

Keterampilan ini tidak dapat berdiri sendiri, karena merupakan implementasi dari kompetensi profesional yang saling terkait dengan kompetensi pedagogik, kepribadian, dan sosial. Dalam penerapannya, keterampilan dasar mengajar harus disesuaikan dengan berbagai keadaan pembelajaran. Dengan demikian keterampilan dasar mengajar tidak dapat dipisahkan dari kompetensi pedagogik. Sebagai kemampuan atau keterampilan pokok dan bersifat khusus, maka mahasiswa sebagai calon guru wajib menguasai dan mampu mengaktualisasikan jenis-jenis keterampilan dasar mengajar dalam pembelajaran.

Ada sepuluh Kompetensi Dasar yang harus dikuasi oleh seorang guru, meliputi:
a. Menguasai bahan/materi pelajaran;
b. Mengelola program pembelajaran;
c. Mengelola kelas;
d. Menggunakan media dan sumber pembelajaran;
e. Menguasai landasan pendidikan;
f. Mengelola interaksi pembelajaran;
g. Menilai prestasi belajar siswa;
h. Mengenal fungsi dan layanan bimbingan dan penyuluhan;
i. Mengenal dan menyelenggarakan administrasi sekolah;
j. Memahami dan menafsirkan hasil penelitian guna keperluan pembelajaran.

Membangun kompetensi pedagogik dan keterampilan dasar mengajar bagi mahasiswa melalui lesson study 
a. Lesson Study

Lesson Study merupakan salah satu upaya pembinaan untuk meningkatkan kualitas pembelajaran yang dilakukan oleh sekelompok guru secara kolaboratif dan berkesinambungan, dalam merencanakan, melaksanakan, mengobservasi dan melaporkan hasil pembelajaran. Kegiatan lesson study dapat mendorong terbentuknya sebuah komunitas belajar (learning society) yang secara konsisten dan sistematis melakukan perbaikan diri, baik pada tataran individual maupun manajerial. Sebagaimana dirumuskan oleh Slamet Mulyana bahwa lesson study sebagai salah satu model pembinaan profesi pendidik melalui pengkajian pembelajaran secara kolaboratif dan berkelanjutan berlandaskan pada prinsipprinsip kolegalitas dan mutual learning untuk membangun komunitas belajar.

b. Langkah-Langkah Lesson Study

Dalam praktiknya ada beberapa variasi atau penyesuaian cara melakasanakan lesson study. Lewis (2002) menyarankan ada enam tahapan dalam awal mengimplementasikan lesson study di sekolah.

Tahap 1:

Membentuk kelompok lesson study, yang antara lain berupa kegiatan merekrut anggota kelompok, menyusun komitmen waktu khusus, menyusun jadwal pertemuan, dan menyetujui aturan kelompok.

Tahap 2:

Memfokuskan lesson study, dengan tiga kegiatan antara utama, yakni: (a) menyepakati tema penelitian (research theme) tujuan jangka panjang bagi peserta didik; (b) memilih cakupan materi; (c) memilih unit pembelajaran dan tujuan yang disepakati.

Tahap 3:

Merencanakan rencana pembelajaran (Research Lesson), yang meliputi kegiatan melakukan pengkajian pembelajaran yang telah ada, mengembangkan petunjuk pembelajaran, meminta masukan dari ahli dalam bidang studi dari luar (dosen atau guru lain yang berpengalaman).

Membangun kompetensi pedagogik dan keterampilan dasar mengajar bagi mahasiswa melalui lesson study 
Tahap 4:

Melaksanakan pembelajaran di kelas dan mengamatinya (observasi). Dalam hal ini pembelajaran dilakukan oleh salah seorang guru anggota kelompok dan anggota yang lain menjadi pengamat. Pengamat tidak diperkenankan melakukan intervensi terhadap jalannya pembelajaran baik kepada guru maupun siswa.

Tahap 5:

Mendiskusikan dan menganalisis pembelajaran, yang telah dilaksanakan. Diskusi dan analisis sebaiknya mencakup butir-butir: refleksi oleh instruktur, informasi latar belakang anggota kelompok, presentasi dan diskusi data dari hasil pengamatan pembelajaran, diskusi umum, komentar dari ahli luar, dan ucapan terima kasih.

Tahap 6:

Merefleksikan pembelajaran dan merencanakan tahap-tahap selanjutnya. Pada tahap ini anggota kelompok diharapkan berpikir tentang apa yang harus dilakukan selanjutnya. Apakah berkeinginan untuk membuat peningkatan agar pembelajaran ini menjadi lebih baik?, apakah akan mengujicobakan di kelas masing-masing?, dan anggota kelompok sudah puas dengan tujuan-tujuan lesson study dan cara kerja kelompok?

\section{METODE PENELITIAN}

\section{Jenis dan Sifat Penelitian}

Jenis penelitian ini adalah penelitian lapangan (field research) dengan subyek mahasiswa semester VI Prodi PGMI Fakultas Tarbiyah dan Keguruan UIN Raden Intan Lampung. Adapun sifat penelitian adalah deskriptif kualitatif. Penelitian deskriptif merupakan penelitian yang dimaksudkan untuk mengumpulkan informasi mengenai status gejala yang ada, yaitu keadaan gejala menurut apa adanya pada saat penelitian dilakukan.

\section{Teknik Pengumpulan Data}

Pengumpulan data penelitian dilakukan melalui triangulasi untuk memperoleh kebenaran informasi yang handal dan gambaran yang utuh mengenai Membangun kompetensi pedagogik dan keterampilan dasar mengajar bagi mahasiswa melalui lesson study 
informasi yang dibutuhkan. Adapun triangulasi yang dimaksud oleh peneliti adalah triangulasi sumber data dan triangulasi metode. Triangulasi sumber data dilakukan untuk mengecek kebenaran data yang sama dari tiga sumber yang berbeda. Sedangkan triangulasi metode dilakukan untuk mengecek kebenaran data melalui tiga teknik yang berbeda, yaitu observasi, wawancara, dan dokumen.

\section{Teknik Analisis Data}

Analisis data dilakukan dengan langkah-langkah sebagai berikut :

a. Data Reduction (Reduksi Data)

Mereduksi data yaitu merangkum data-data yang terkumpul dari lapangan kemudian memilih hal-hal yang pokok sesuai dengan fokus penelitian.

Jadi dalam penelitian ini, peneliti merangkum data yang diperoleh dari implementasi lesson study dalam membangun kompetensi pedagogik dan keterampilan dasar mengajar mahasiswa.

b. Data Display (Penyajian Data)

Pada penelitian ini, peneliti menyajikan hasil dari implementasi lesson study dalam membangun kompetensi pedagogik dan keterampilan dasar mengajar mahasiswa.

c. Verifikasi

Langkah ketiga dalam analisis data kualitatif adalah penarikan kesimpulan dan verifikasi. Untuk menarik kesimpulan peneliti menggunakan cara berfikir induktif atau analisis sintetik. Peneliti menganalisa data berdasarkan fakta-fakta khusus untuk menghasilkan kesimpulan yang akurat, sehingga dapat dijadikan fakta dalam membuktikan kebenaran data yang diajukan.

\section{HASIL PENELITIAN}

Penelitian diawali dengan memberikan pemahaman kepada mahasiswa mengenai konsep-konsep kompetensi pedagogik dan keterampilan dasar mengajar. Mengingat bahwa subyek penelitian merupakan mahasiswa yang belum sepenuhnya menjadi praktisi pendidik atau guru, sehingga mereka perlu menguasai apa yang dimaksud dengan kompetensi pedagogik dan keterampilan Membangun kompetensi pedagogik dan keterampilan dasar mengajar bagi mahasiswa melalui lesson study 
TERAMPIL

Jurnal Pendidikan dan Pembelajaran Dasar

Volume 5 Nomor 1 Juni 2018

p-ISSN 2355-1925

e-ISSN 2580-8915

dasar mengajar serta bagaimana mengimplementasikannya dalam proses pembelajara yang sesungguhnya.

Berdasarkan teori-teori yang diberikan oleh peneliti yang juga menjadi dosen pembimbing, selanjutnya mahasiswa diberi kesempatan untuk menyusun rancangan observasi yang dibutuhkan untuk mengumpulkan data-data penelitian. Berbagai ide dan masukan dari masing-masing kelompok kemudian didiskusikan di kelas untuk menemukan konsep yang sama sehingga hasilnya kelak tidak menyimpang dari tujuan utama penelitian.

Peneliti merangkum pendapat para ahli sehingga kemudian disusun kisikisi observasi sebagai berikut.

Tabel 1

Kisi-Kisi Observasi

\begin{tabular}{|c|c|c|c|c|c|}
\hline No & $\begin{array}{c}\text { Jenis } \\
\text { Keterampilan }\end{array}$ & & Indikator & Sub-Indikator & Ket. \\
\hline \multirow[t]{15}{*}{1} & \multirow{15}{*}{$\begin{array}{l}\text { Keterampilan } \\
\text { Membuka } \\
\text { Pembelajaran }\end{array}$} & \multirow[t]{4}{*}{ 1) } & \multirow{4}{*}{$\begin{array}{l}\text { Mengkondi } \\
\text { sikan } \\
\text { pembela- } \\
\text { jaran }\end{array}$} & a. Menumbuhkan perhatian dan motivasi & \\
\hline & & & & b. Menciptakan sikap yang mendidik & \\
\hline & & & & c. Menciptakan kesiapan belajar siswa & \\
\hline & & & & d. Menciptakan suasana belajar yang demokratis & \\
\hline & & & \multirow{3}{*}{$\begin{array}{l}\text { Menarik } \\
\text { perhatian } \\
\text { siswa }\end{array}$} & a. Gaya mengajar guru & \\
\hline & & & & b. Penggunaan alat bantu & \\
\hline & & & & c. Menciptakan interaksi & \\
\hline & & & \multirow{4}{*}{$\begin{array}{l}\text { Memberi- } \\
\text { kan } \\
\text { motivasi }\end{array}$} & a. Memperhatikan minat siswa & \\
\hline & & & & b. Menimbulkan antusias belajar & \\
\hline & & & & c. Menimbulkan rasa ingin tahu & \\
\hline & & & & d. Mengemukakan soal atau pertanyaan & \\
\hline & & & \multirow{4}{*}{$\begin{array}{l}\text { Melaksa- } \\
\text { nakan } \\
\text { Kegiatan } \\
\text { Apersepsi }\end{array}$} & a. Mengecek kehadiran siswa & \\
\hline & & & & $\begin{array}{l}\text { b. Mengaitkan materi yang akan dipelajari } \\
\text { dengan materi sebelumnya }\end{array}$ & \\
\hline & & & & c. Menyampaikan kompetensi yang akan dicapai & \\
\hline & & & & $\begin{array}{l}\text { d. Menjelaskan kegiatan yang harus dilakukan } \\
\text { siswa }\end{array}$ & \\
\hline \multirow[t]{3}{*}{2} & \multirow{3}{*}{$\begin{array}{l}\text { Keterampilan } \\
\text { Menjelaskan } \\
\text { Pembelajaran }\end{array}$} & \multirow{3}{*}{\multicolumn{2}{|c|}{ 1) Kejelasan }} & a. Kalimat sederhana / tidak berbelit- belit & \\
\hline & & & & $\begin{array}{l}\text { b. Penggunaan kata-kata tidak berlebihan atau } \\
\text { tidak meragukan }\end{array}$ & \\
\hline & & & & $\begin{array}{l}\text { c. Melengkapi penjelasan dengan memberikan } \\
\text { contoh-contoh yang aktual dan sesuai materi }\end{array}$ & \\
\hline
\end{tabular}

Membangun kompetensi pedagogik dan keterampilan dasar mengajar bagi mahasiswa melalui lesson study 
TERAMPIL

Jurnal Pendidikan dan Pembelajaran Dasar

Volume 5 Nomor 1 Juni 2018

p-ISSN 2355-1925

e-ISSN 2580-8915

\begin{tabular}{|c|c|c|c|c|c|}
\hline No & $\begin{array}{c}\text { Jenis } \\
\text { Keterampilan }\end{array}$ & & Indikator & Sub-Indikator & Ket. \\
\hline & & \multirow{3}{*}{\multicolumn{2}{|c|}{$\begin{array}{l}\text { 2) Interaksi } \\
\text { dalam } \\
\text { pembela- } \\
\text { jaran }\end{array}$}} & a. Mendorong siswa aktif dalam pembelajaran & \\
\hline & & & & $\begin{array}{l}\text { b. Memberi bantuan kepada siswa yang } \\
\text { mengalami kesulitan }\end{array}$ & \\
\hline & $\begin{array}{l}\text { Keterampilan } \\
\text { Mengadakan } \\
\text { Variasi Stimulus }\end{array}$ & & & c. Merespon siswa & \\
\hline \multirow[t]{10}{*}{3} & \multirow{5}{*}{$\begin{array}{l}\text { Keterampilan } \\
\text { Mengadakan } \\
\text { Variasi Stimulus }\end{array}$} & \multirow{5}{*}{\multicolumn{2}{|c|}{$\begin{array}{l}\text { 1) Variasi } \\
\text { gaya } \\
\text { belajar }\end{array}$}} & a. Nada dan volume suara, \& kecepatan bicara & \\
\hline & & & & $\begin{array}{l}\text { b. Mimik dan gerak tubuh dalam menjelaskan } \\
\text { materi pembelajaran }\end{array}$ & \\
\hline & & & & c. Posisi dan gerak tubuh & \\
\hline & & & & $\begin{array}{l}\text { d. Kesenyapan, hening, dalam menjelaskan } \\
\text { materi pembelajaran }\end{array}$ & \\
\hline & & & & e. Jarak pandang dengan siswa & \\
\hline & & \multirow{3}{*}{\multicolumn{2}{|c|}{$\begin{array}{l}\text { 2) Variasi } \\
\text { dalam pola } \\
\text { interaksi }\end{array}$}} & a. Variasi pendekatan \& model pembelajaran & \\
\hline & & & & b. Variasi metode pembelajaran & \\
\hline & & & & c. Variasi strategi pembelajaran & \\
\hline & & & \multirow{2}{*}{$\begin{array}{l}\text { Variasi } \\
\text { pengguna- } \\
\text { an media } \\
\text { pembelajar } \\
\text { an }\end{array}$} & a. Penggunaan media audio, visual, audio-visual & \\
\hline & & & & b. Melibatkan siswa dalam penggunaan media & \\
\hline \multirow[t]{8}{*}{4} & \multirow[t]{8}{*}{$\begin{array}{l}\text { Keterampilan } \\
\text { Bertanya Dasar }\end{array}$} & & & $\begin{array}{l}\text { a. Mengungkapkan pertanyaan secara jelas dan } \\
\text { singkat }\end{array}$ & \\
\hline & & & & $\begin{array}{l}\text { b. Pemberian acuan agar siswa dapat menjawab } \\
\text { dengan tepat }\end{array}$ & \\
\hline & & & & c. Pemusatan pada jawaban yang diminta & \\
\hline & & & & d. Pemindahan giliran menjawab & \\
\hline & & & & e. Pertanyaan menyebar ke seluruh kelas & \\
\hline & & & & f. Pemberian waktu berfikir & \\
\hline & & & & $\begin{array}{l}\text { g. Pertanyaan dengan memberikan tuntunan } \\
\text { 1) Mengungkapkan pertanyaan dengan cara } \\
\text { lain }\end{array}$ & \\
\hline & & & & 2) Mengarahkan jawaban kepada yang dituju & \\
\hline \multirow[t]{6}{*}{5} & \multirow{6}{*}{$\begin{array}{l}\text { Keterampilan } \\
\text { Bertanya Lanjut }\end{array}$} & \multirow[t]{6}{*}{ 1) } & \multirow{6}{*}{$\begin{array}{l}\text { Pengubah- } \\
\text { an tuntunan } \\
\text { kognitif } \\
\text { dalam } \\
\text { menjawab } \\
\text { pertanyaan }\end{array}$} & a. Ingatan & \\
\hline & & & & b. Pemahaman & \\
\hline & & & & c. Penerapan & \\
\hline & & & & d. Analisis & \\
\hline & & & & e. Sintesis & \\
\hline & & & & f. Evaluasi & \\
\hline
\end{tabular}

Membangun kompetensi pedagogik dan keterampilan dasar mengajar bagi mahasiswa melalui lesson study 
TERAMPIL

Jurnal Pendidikan dan Pembelajaran Dasar

Volume 5 Nomor 1 Juni 2018

p-ISSN 2355-1925

e-ISSN 2580-8915

\begin{tabular}{|c|c|c|c|c|c|}
\hline No & $\begin{array}{c}\text { Jenis } \\
\text { Keterampilan }\end{array}$ & & Indikator & Sub-Indikator & Ket. \\
\hline & & \multirow[t]{2}{*}{ 2) } & \multirow{2}{*}{$\begin{array}{l}\text { Urutan } \\
\text { Pertanyaan }\end{array}$} & a. Urutan pertanyaan sistematis & \\
\hline & & & & b. Urutan pertanyaan logis & \\
\hline & & \multirow[t]{6}{*}{ 3) } & \multirow{6}{*}{$\begin{array}{l}\text { Pertanya- } \\
\text { an Pelacak }\end{array}$} & a. Klarifikasi & \\
\hline & & & & b. Pemberian alasan & \\
\hline & & & & c. Kesepakatan pandangan & \\
\hline & & & & d. Ketepatan & \\
\hline & & & & e. Memberi contoh yang relevan & \\
\hline & & & & f. Memberi jawaban kompleks & \\
\hline & & & $\begin{array}{l}\text { Mendorong } \\
\text { terjadinya } \\
\text { interaksi } \\
\text { antar siswa }\end{array}$ & & \\
\hline \multirow[t]{9}{*}{6} & \multirow{9}{*}{$\begin{array}{l}\text { Keterampilan } \\
\text { Memberi } \\
\text { Penguatan }\end{array}$} & \multirow[t]{3}{*}{ 1) } & \multirow{3}{*}{$\begin{array}{l}\text { Penguat-an } \\
\text { verbal } \\
\text { dengan } \\
\text { kata }\end{array}$} & a. Bagus & \\
\hline & & & & b. Baik & \\
\hline & & & & c. Tepat & \\
\hline & & \multirow[t]{3}{*}{ 2) } & \multirow{3}{*}{$\begin{array}{l}\text { Penguatan } \\
\text { verbal } \\
\text { dengan } \\
\text { kalimat } \\
\end{array}$} & a. Jawabanmu tepat sekali & \\
\hline & & & & b. Saya senang dengan jawabanmu & \\
\hline & & & & c. Pendapatmu makin mantap & \\
\hline & & \multirow[t]{3}{*}{ 3) } & \multirow{3}{*}{$\begin{array}{l}\text { Penguatan } \\
\text { Non-Verbal }\end{array}$} & a. Sentuhan & \\
\hline & & & & b. Mendekati & \\
\hline & & & & c. Isyarat & \\
\hline \multirow[t]{13}{*}{7} & \multirow{12}{*}{$\begin{array}{l}\text { Keterampilan } \\
\text { Membimbing } \\
\text { Diskusi }\end{array}$} & \multirow[t]{3}{*}{ 1) } & \multirow{3}{*}{$\begin{array}{l}\text { Memusat- } \\
\text { kan } \\
\text { perhatian }\end{array}$} & a. Merumuskan tujuan diskusi & \\
\hline & & & & b. Merumuskan masalah yang dibahas & \\
\hline & & & & c. Membuat rangkuman permasalahan diskusi & \\
\hline & & \multirow[t]{3}{*}{ 2) } & \multirow{3}{*}{$\begin{array}{l}\text { Memperje- } \\
\text { las masalah } \\
\text { dan urutan } \\
\text { pendapat }\end{array}$} & a. Merangkum pendapat siswa & \\
\hline & & & & $\begin{array}{l}\text { b. Menggali ide dan pendapat siswa pada saat } \\
\text { diskusi }\end{array}$ & \\
\hline & & & & $\begin{array}{l}\text { c. Mengurai secara rinci pendpat yang dimaksud } \\
\text { siswa dalam }\end{array}$ & \\
\hline & & \multirow[t]{2}{*}{ 3) } & \multirow{2}{*}{$\begin{array}{l}\text { Menganali- } \\
\text { sa pan- } \\
\text { dangan } \\
\text { siswa } \\
\end{array}$} & a. Menandai persetujuan & \\
\hline & & & & b. Meneliti alasannya & \\
\hline & & & \multirow{4}{*}{$\begin{array}{l}\text { Mening- } \\
\text { katkan } \\
\text { urutan } \\
\text { siswa }\end{array}$} & a. Menimbulkan pertanyaan & \\
\hline & & & & b. Menggunakan contoh & \\
\hline & & & & c. Menunggu urutan bicara & \\
\hline & & & & d. Memberi dukungan pada teman & \\
\hline & & 5) & Menye- & a. Meneliti pandangan & \\
\hline
\end{tabular}

Membangun kompetensi pedagogik dan keterampilan dasar mengajar bagi mahasiswa melalui lesson study 
TERAMPIL

Jurnal Pendidikan dan Pembelajaran Dasar

Volume 5 Nomor 1 Juni 2018

p-ISSN 2355-1925

e-ISSN 2580-8915

\begin{tabular}{|c|c|c|c|c|}
\hline No & $\begin{array}{l}\text { Jenis } \\
\text { Keterampilan }\end{array}$ & Indikator & Sub-Indikator & Ket. \\
\hline & & \multirow{2}{*}{$\begin{array}{l}\text { barkan } \\
\text { kesempatan } \\
\text { berpartisi- } \\
\text { pasi }\end{array}$} & & \\
\hline & & & b. Menghindari monopoli diskusi & \\
\hline & & \multirow{2}{*}{$\begin{array}{l}\text { 6) Menutup } \\
\text { diskusi }\end{array}$} & a. Merangkum hasil diskusi & \\
\hline & & & b. Menilai keseluruhan jalannya diskusi & \\
\hline \multirow[t]{20}{*}{8} & \multirow{20}{*}{$\begin{array}{l}\text { Keterampilan } \\
\text { Mengajar } \\
\text { Kelompok Kecil } \\
\text { \& Perorangan }\end{array}$} & \multirow{7}{*}{$\begin{array}{l}\text { 1) Keterampil } \\
\text { an } \\
\text { mengada- } \\
\text { kan } \\
\text { pendekatan } \\
\text { pribadi }\end{array}$} & $\begin{array}{l}\text { a. Menunjukkan kehangatan dan kepekaan } \\
\text { terhadap siswa }\end{array}$ & \\
\hline & & & b. Mendengarkan gagasan siswa & \\
\hline & & & c. Merespon siswa secara positif & \\
\hline & & & d. Membangun hubungan saling percaya & \\
\hline & & & e. Membantu siswa & \\
\hline & & & f. Tanggap pada perasaan siswa & \\
\hline & & & $\begin{array}{l}\text { g. Menimbulkan rasa aman dan merasa terbantu } \\
\text { bagi siswa }\end{array}$ & \\
\hline & & \multirow{6}{*}{$\begin{array}{l}\text { 2) Keterampil } \\
\text { an mengor- } \\
\text { ganisasi } \\
\text { kegiatan } \\
\text { pembela- } \\
\text { jaran }\end{array}$} & $\begin{array}{l}\text { a. Memberikan orientasi tentang tujuan, tugas, } \\
\text { dan cara mengerjakannya }\end{array}$ & \\
\hline & & & $\begin{array}{l}\text { b. Mencegah kebosanan siswa dalam } \\
\text { pembelajaran }\end{array}$ & \\
\hline & & & c. Membentuk kelompok yang tetap & \\
\hline & & & $\begin{array}{l}\text { d. Mengkoordinasi kegiatan kelompok kecil/ } \\
\text { perorangan }\end{array}$ & \\
\hline & & & e. Membagi perhatian terhadap kebutuhan siswa & \\
\hline & & & f. Mengakhiri kegiatan dengan kulminasi & \\
\hline & & \multirow{3}{*}{$\begin{array}{l}\text { Keterampil } \\
\text { an mem- } \\
\text { bimbing } \\
\text { dan } \\
\text { memberi } \\
\text { kemudahan } \\
\text { belajar }\end{array}$} & a. Memberi penguatan secara tepat & \\
\hline & & & b. Melaksanakan supervisi proses awal & \\
\hline & & & c. Melaksanakan supervisi proses lanjut & \\
\hline & & \multirow{4}{*}{$\begin{array}{l}\text { Keterampil } \\
\text { an meran- } \\
\text { cang dan } \\
\text { melaksa- } \\
\text { nakan } \\
\text { kegiatan } \\
\text { pembela- } \\
\text { jaran }\end{array}$} & a. Membantu siswa menetapkan tujuan belajar & \\
\hline & & & b. Merancang kegiatan belajar & \\
\hline & & & c. Bertindak sebagai penasihat siswa & \\
\hline & & & $\begin{array}{l}\text { d. Membantu siswa menilai kemajuan belajarnya } \\
\text { sendiri }\end{array}$ & \\
\hline 9 & $\begin{array}{l}\text { Keterampilan } \\
\text { Membuat }\end{array}$ & & $\begin{array}{l}\text { a. Memberikan ilustrasi yang mudah dipahami } \\
\text { siswa }\end{array}$ & \\
\hline
\end{tabular}

Membangun kompetensi pedagogik dan keterampilan dasar mengajar bagi mahasiswa melalui lesson study 
TERAMPIL

Jurnal Pendidikan dan Pembelajaran Dasar

Volume 5 Nomor 1 Juni 2018

p-ISSN 2355-1925

e-ISSN 2580-8915

\begin{tabular}{|c|c|c|c|c|}
\hline No & $\begin{array}{l}\text { Jenis } \\
\text { Keterampilan }\end{array}$ & Indikator & Sub-Indikator & Ket. \\
\hline & $\begin{array}{l}\text { Ilustrasi \& } \\
\text { Contoh }\end{array}$ & & $\begin{array}{l}\text { b. Memberikan ilustrasi yang menarik pehatian } \\
\text { siswa }\end{array}$ & \\
\hline & & & $\begin{array}{l}\text { c. Memberikan contoh yang relevan dengan } \\
\text { kehidupan nyata }\end{array}$ & \\
\hline & & & $\begin{array}{l}\text { d. Memberikan contoh yang sesuai dengan usia } \\
\text { siswa }\end{array}$ & \\
\hline \multirow[t]{2}{*}{10} & \multirow[t]{2}{*}{$\begin{array}{l}\text { Keterampilan } \\
\text { Mengelola Kelas }\end{array}$} & \multirow[t]{2}{*}{$\begin{array}{l}\text { 1) Bersikap } \\
\text { tanggap }\end{array}$} & $\begin{array}{l}\text { a. Bersikap tanggap/responsif terhadap } \\
\text { permasalahan \& pertanyaan yang disampaikan } \\
\text { siswa }\end{array}$ & \\
\hline & & & b. Gerakan mendekati & \\
\hline & & & $\begin{array}{l}\text { c. Memberikan teguran bila siswa melakukan } \\
\text { tindakan yang menyimpang dengan aturan }\end{array}$ & \\
\hline & & \multirow{2}{*}{$\begin{array}{l}\text { 2) } \text { Memberi } \\
\text { perhatian }\end{array}$} & a. Secara visual & \\
\hline & & & b. Secara Verbal & \\
\hline & & \multirow{3}{*}{$\begin{array}{l}\text { 3) Memusatka } \\
\text { n Perhatian } \\
\text { Kompleks }\end{array}$} & a. Menyiapkan materi yang akan disajikan & \\
\hline & & & b. Mengarahkan perhatian & \\
\hline & & & c. Menyusun komentar & \\
\hline & & \multirow{2}{*}{$\begin{array}{l}\text { 4) Menun-tut } \\
\text { perhatian } \\
\text { siswa }\end{array}$} & a. Menyuruh siswa lain mengoreksi temannya & \\
\hline & & & $\begin{array}{l}\text { b. Menyuruh siswa menyerahkan hasil } \\
\text { pekerjaannya }\end{array}$ & \\
\hline & & \multirow{2}{*}{$\begin{array}{l}\text { 5) Petunjuk } \\
\text { yang jelas }\end{array}$} & a. Kepada seluruh kelas & \\
\hline & & & b. Kepada individu & \\
\hline \multirow[t]{6}{*}{11} & \multirow{6}{*}{$\begin{array}{l}\text { Keterampilan } \\
\text { Menutup } \\
\text { Pembelajaran }\end{array}$} & & a. Meninjau kembali materi yang telah diberikan & \\
\hline & & & b. Merangkum seluruh materi & \\
\hline & & & c. Menyimpulkan pembelajaran & \\
\hline & & & d. Melakukan refleksi & \\
\hline & & & e. Melakukan evaluasi & \\
\hline & & & $\begin{array}{l}\text { f. Merencanakan dan menjelaskan tindak lanjut } \\
\text { berikutnya }\end{array}$ & \\
\hline
\end{tabular}

Membangun kompetensi pedagogik dan keterampilan dasar mengajar bagi mahasiswa melalui lesson study 


\section{E. PEMBAHASAN}

e-ISSN 2580-8915

Hasil analisa data yang diperoleh dari observasi:

\begin{tabular}{|c|c|}
\hline NO & JENIS KOMPETENSI/KETERAMPILAN \& ANALISANYA \\
\hline \multirow[t]{4}{*}{1.} & Membuka Pembelajaran \\
\hline & HASIL ANALISA \\
\hline & $\begin{array}{l}\text { Ssemua unsur yang terdapat dalam sub-indikator keterampilan membuka } \\
\text { pembelajaran telah dilaksanakan dengan lengkap, sistematis, dan terencana. } \\
\text { Aktivitas guru dan peserta didik menunjukkan bahwa guru telah } \\
\text { merencanakan sebaik mungkin setiap detil yang harus dilakukan guru untuk } \\
\text { mempersiapkan peserta didiknya melakukan proses pembelajaran. }\end{array}$ \\
\hline & $\begin{array}{l}\text { Cerita singkat yang cukup menarik perhatian peserta didik membuktikan } \\
\text { bahwa guru memahami karakter peserta didiknya sesuai dengan levelnya. } \\
\text { Pertanyaan di awal pembelajaran menimbulkan minat dan rasa ingin tahu } \\
\text { peserta didik, sehingga mereka menjadi termotivasi untuk terus mengikuti } \\
\text { pembelajaran. Hal ini menunjukkan bahwa mahasiswa telah memahami } \\
\text { bagaimana mengimplementasikan dan mengembangkan kompetensi } \\
\text { pedagogik dalam memahami karakteristik peserta didik. }\end{array}$ \\
\hline \multirow[t]{3}{*}{2.} & Menjelaskan Pembelajaran \\
\hline & HASIL ANALISA \\
\hline & $\begin{array}{l}\text { Guru mampu menjelaskan pembelajaran dengan baik. Penggunaan kata-kata } \\
\text { yang sederhana, bahasa yang jelas, dan pemberian contoh yang tepat, } \\
\text { membuat peserta didik jadi mudah memahami materi yang diberikan. } \\
\text { Interaksi dua arah dan respons positif yang diciptakan guru dapat } \\
\text { memancing partisipasi aktif peserta didik selama proses pembelajaran. }\end{array}$ \\
\hline \multirow[t]{4}{*}{3.} & Mengadakan Variasi Stimulus \\
\hline & HASIL ANALISA \\
\hline & $\begin{array}{l}\text { Guru menggunakan nada suara yang stabil dengan mimik wajah yang tepat } \\
\text { sesuai pembelajaran. Posisi guru tidak hanya pada satu tempat yang sama } \\
\text { dan kontak mata yang dilakukan guru, serta metode pembelajaran yang } \\
\text { bervariasi dapat menjadi stimulus untuk mendapatkan respons peserta didik. }\end{array}$ \\
\hline & $\begin{array}{l}\text { Namun stimulus yang diberikan guru kurang optimal diantaranya karena } \\
\text { interaksi yang terjadi hanya guru - peserta didik, dan peserta didik - guru. } \\
\text { Tidak ada kesempatan interaksi peserta didik - peserta didik yang diciptakan } \\
\text { oleh guru. Media yang digunakan juga hanya terbatas pada media visual. }\end{array}$ \\
\hline 4. & Bertanya Dasar \\
\hline
\end{tabular}

Membangun kompetensi pedagogik dan keterampilan dasar mengajar bagi mahasiswa melalui lesson study 


\begin{tabular}{|c|c|}
\hline NO & JENIS KOMPETENSI/KETERAMPILAN \& ANALISANYA \\
\hline & HASIL ANALISA \\
\hline & $\begin{array}{l}\text { Guru menguasai keterampilan bertanya dasar dengan sangat baik. Terbukti } \\
\text { dari teknik bertanya yang dilakukan guru, yaitu: memberi acuan, bertanya } \\
\text { secara umum, memberi kesempatan berpikir sebelum menunjuk seseorang } \\
\text { untuk menjawab, dan membimbing peserta didik agar mampu menemukan } \\
\text { sendiri jawaban yang tepat. }\end{array}$ \\
\hline \multirow[t]{3}{*}{5.} & Bertanya Lanjut \\
\hline & HASIL ANALISA \\
\hline & $\begin{array}{l}\text { Keterampilan bertanya lanjut hanya sebatas pada kompetensi kognitif berupa } \\
\text { ingatan dan hapalan. Guru belum mampu mengembangkan pertanyaan yang } \\
\text { jawabannya membutuhkan analisa, sintetis, atau kemampuan psikomotorik. }\end{array}$ \\
\hline \multirow[t]{3}{*}{6.} & Memberi Penguatan \\
\hline & HASIL ANALISA \\
\hline & $\begin{array}{l}\text { Penguatan dibutuhkan untuk menunjukkan apresiasi bagi peserta didik yang } \\
\text { mampu melakukan kegiatan atau mencapai tujuan yang diinginkan. Dari } \\
\text { praktik mengajar, nampak jelas bahwa mahasiswa sudah menguasai } \\
\text { keterampilan memberi penguatan. Karena mereka sudah menerapkan } \\
\text { berbagai teknik memberi penguatan, baik penguatan verbal maupun non- } \\
\text { verbal. }\end{array}$ \\
\hline \multirow[t]{3}{*}{7.} & Membimbing Diskusi \\
\hline & HASIL ANALISA \\
\hline & $\begin{array}{l}\text { Beranggapan bahwa keterampilan membimbing diskusi hanya diterapkan } \\
\text { jika pembelajaran menggunakan metode diskusi. Karena dalam kegiatan } \\
\text { lesson study masih ada kelompok tidak mempraktikkan metode diskusi } \\
\text { dalam proses pembelajaran yang mereka rancang, sehingga keterampilan } \\
\text { membimbing diskusi tidak diterapkan sama sekali. }\end{array}$ \\
\hline \multirow[t]{3}{*}{8.} & Mengajar Kelompok Kecil dan Perorangan \\
\hline & HASIL ANALISA \\
\hline & $\begin{array}{l}\text { Keterampilan mengajar kelompok kecil atau perorangan belum berkembang } \\
\text { dengan baik karena banyak indikator yang menjadi ciri keterampilan ini } \\
\text { belum dilaksanakan dengan baik. Selain guru tidak melakukan kulminasi, } \\
\text { guru juga tidak mengkoordinir kerja kelompok, melakukan supervisi, atau } \\
\text { menyampaikan nasihat-nasihat kehidupan kepada peserta didik. Guru tidak } \\
\text { melibatkan peserta didik dalam menentukan tujuan belajar dan tidak }\end{array}$ \\
\hline
\end{tabular}

Membangun kompetensi pedagogik dan keterampilan dasar mengajar bagi mahasiswa melalui lesson study 


\begin{tabular}{|c|l|}
\hline NO & \multicolumn{1}{|c|}{ JENIS KOMPETENSI/KETERAMPILAN \& ANALISANYA } \\
\hline 9. & Menuntun peserta didik agar dapat menilai sendiri kemajuan belajar mereka. \\
\hline Membuat Ilustrasi dan Contoh \\
$\begin{array}{l}\text { HASIL ANALISA } \\
\text { Sudah mengembangkan keterampilan membuat ilustrasi dan contoh dengan } \\
\text { menarik, juga relevan dengan kehidupan nyata. }\end{array}$ \\
\hline 10. & $\begin{array}{l}\text { Mengelola Kelas } \\
\text { HASIL ANALISA } \\
\text { Keterampilan mengelola kelas dapat dikuasai dengan baik. Guru memberi } \\
\text { perhatian kepada seluruh peserta didik, memberi kesempatan yang sama } \\
\text { bagi mereka untuk mengembangkan diri, dan mampu menjaga ketertiban } \\
\text { kelas selama proses pembelajaran. }\end{array}$ \\
\hline 11. & $\begin{array}{l}\text { Menutup Pembelajaran } \\
\text { HASIL ANALISA } \\
\text { Mahasiswa dalam praktik mengajar mampu menguasai keterampilan } \\
\text { menutup pembelajaran dengan cukup baik. Guru menutup pembelajaran } \\
\text { dengan mengajak peserta didik merangkum pelajaran, melakukan evaluasi, } \\
\text { dan menyampaikan rencana pembelajaran selanjutnya. Perbedaan yang } \\
\text { cukup jelas terlihat adalah pada kegiatan refleksi, hanya sebagian kecil } \\
\text { mahasiswayang melakukan refleksi saat menutup pembelajaran. }\end{array}$ \\
\hline
\end{tabular}

\section{F. KESIMPULAN}

Berdasarkah hasil analisa dari data-data yang diperoleh dalam penelitian, maka diperoleh kesimpulan sebagai berikut:

1. Pelaksanaan lesson study menumbuhkan kompetensi pedagogik dan keterampilan dasar mengajar mahasiswa melalui komitmen yang kuat dari seluruh anggota tim, proses latihan mengajar yang terencana secara seksama, pelaksanaan yang dilakukan dengan tahapan yang sistematis dan berkelanjutan, serta saling memberi dan menerima saran dari orang lain.

2. Kendala-kendala yang dihadapi:

Membangun kompetensi pedagogik dan keterampilan dasar mengajar bagi mahasiswa melalui lesson study 
a. Keberadaan observer yang jumlahnya cukup banyak dapat mengganggu konsentrasi pengajar sehingga proses pembelajaran juga terganggu.

b. Seringkali observer hanya mencatat kesalahan/kekurangan selama proses pembelajaran.

c. Kebanyakan fokus pengamatan pada guru, bukan pada proses pembelajaran.

d. Pada tahapan diskusi, seringkali yang terjadi adalah: mahasiswa saling mengritik dan mengemukakan kelemahan rekannya. Padahal semestinya mereka saling belajar satu dengan lainnya.

3. Manfaat Lesson Study dalam membangun kompetensi pedagogik dan keterampilan dasar mengajar bagi mahasiswa:

a. Menumbuhkan kemampuan mengamati dan belajar dari pengalaman orang lain.

b. Memberi kesempatan untuk berlatih berulang kali sehingga berdampak pada kualitas pembelajaran yang lebih baik.

c. Melatih mahasiswa untuk lebih teliti dalam menentukan tujuan pembelajaran, mengenal cara berpikir peserta didik, dan memilih metode pembelajaran yang tepat.

d. Dapat mengembangkan keahlian mengajar baik dalam perencanaan maupun selama proses pembelajaran.

\section{G. DAFTAR PUSTAKA}

Arikunto, Suharsimi. 2001. Prosedur Penelitian Suatu Pendekatan Praktik cet. Ke-4. Rineka Cipta. Jakarta.

Antonius. 2016. Buku Pedoman Guru. Yrama Widya. Bandung.

Asril, Zainal. 2015. Microteaching Edisi Kedua. PT. Raja Grafindo Persada. Jakarta.

Barnawi dan M. Arifin. 2016. Microteaching: Teori \& Praktik Pengajaran yang Efektif \& Kreatif. Ar-Ruzz Media. Jakarta.

Ikhrom. 2015. Menyoal Kinerja Guru. Kaukaba Dipantara. Yokyakarta.

Forum Guru, "Empat Jenis Kompetensi Guru dan Penjelasannya”, http://forumguru.net/4-jenis-kompetensi-guru-dan-penjelasannyal

Membangun kompetensi pedagogik dan keterampilan dasar mengajar bagi mahasiswa melalui lesson study 
Hadi, Sutrisno. 2004. Metodelogi Research cet. Ke 1. Penerbit Andi. Yogyakarta. . 2004. Metodelogi Research cet. Ke 2, Penerbit Andi. Yogyakarta. .2004. Metodologi Research Jilid 1. Andi Offset. Yogyakarta.

Undang-undang. 2013. Himpunan Lengkap Undang-Undang Sisdiknas dan Sertifikasi Guru. Buku Biru. Jogjakarta.

Kamars, M. Dachniel. 1994. Kurikulum Untuk Abad 21 dalam Model Pengelolaan dan Penelitian Kurikulum. Gramedia Widiasarana Indonesia. Jakarta.

Kunandar. 2009. Guru Profesional; Implementasi Kurikulum Tingkat Satuan Pendidikan (KTSP) dan Sukses dalam Sertifikasi Guru. Rajawali Pers. Jakarta.

Leanne Miller. "Taking Professional Learning into the Classroom". http://www.oct.ca/home.aspx?

Oktafian Budi "Lesson Study", http://gugustunasbangsa.blogspot.co.id/2012/03/lesson-study.html

Moleong, Lexy J. 2009. Metodelogi Penelitian Kualitatif (Edisi Revisi). PT Remaja Rosdakarya. Bandung.

Rusman. 2013. Model-Model Pembelajaran Mengembangkan Profesionalisme Guru. Rajawali Pers. Jakarta.

S. Nasution. 1996. Metode Research (Penelitian Ilmiah), Jakarta: Bumi Aksara, Syafrina, Nur Indah, "Lesson Study", http://lpmpriau.go.id/?p=210

Saebani, Beni Ahmad. 2008. Metode Penelitian. Pustaka Setia. Bandung.

Satori, Djam'an, et.al. 2013. Profesi Keguruan. Universitas Terbuka Cet.16.edisi1. Tanggrang Selatan.

Sugiyono. 2009. Metode Penelitian Pendidikan (Pendekatan Kuantitatif, Kualitatif, Dan R\&D). Alfabeta. Bandung.

Tuckman. 1978. Conducting Educational Research. Harcourt Brace Javanovich INC. New York.

Undang-undang. 2006. Undang-Undang RI nomor 14 Tahun 2005 tentang Guru dan Dosen, \& Peraturan Mendiknas Nomor 11 Tahun 2005. Citra Umbara. Bandung.

Winarno , J.B. Situmorang. 2008. Pendidikan Profesi \& Sertifikasi Pendidik. Saka Mitra Kompetensi. Klaten.

Membangun kompetensi pedagogik dan keterampilan dasar mengajar bagi mahasiswa melalui lesson study 